\title{
Stock Prices Behavior Before and After Friday the $13^{\text {th }}$
}

\author{
Ramona Dumitriu' \\ rdumitriu@,ugal.ro \\ Razvan Stefanescu \\ rstefanescu@,ugal.ro \\ Dunarea de Jos University of Galati, Romania
}

\begin{abstract}
Empirical researches proved that many calendar anomalies of the financial markets were not persistent in time. Sometimes, the abnormal returns, detected for specific trading days, migrated to adjacent days. This paper explores the changes suffered by Friday the $13^{\text {th }}$ Effect on the four indexes of the US stock market during three periods: January 1990 - December 1999, January 2000 - December 2007 and January 2008 - April 2019. For the first period we found, for two of the four indexes, that returns on Friday the $13^{\text {th }}$ were significant higher than the average. During the second period, for three of the four indexes, the returns were higher than the average on the trading day that follows Friday the $13^{\text {th }}$. For this period we also found abnormal volatility on the trading days that precede or follow Friday the $13^{\text {th }}$. In case of third period, the returns were significant lower on the two trading days before and significant higher three trading days after.
\end{abstract}

Keywords: calendar anomalies, stock returns, superstition, volatility

JEL: G40, G41, G14

\section{Introduction}

Several studies from the field of behavioral finance concentrated on the factors that could bound the rationality of the investment decisions. Among them, the superstitions shared by investors have a particular position being so obvious irrational (Hirshleifer et al., 2016). In the Western culture, one of the main superstitions is associated to the supposed unluckiness of the Fridays that fall on the $13^{\text {th }}$ of a month. On the financial markets, the fear of bad luck could influence the investors' behavior on these days. Kolb \& Rodriguez (1987) examined the US capital market evolution between July 1962 and December 1985 finding that stock returns from Fridays the $13^{\text {th }}$ of are significant lower than those from the other Fridays. This form of seasonality, which challenged the principles of the Efficient Market Hypothesis (EMH), was viewed as a calendar anomaly that took the name of Friday the $13^{\text {th }}$ Effect.

Other investigations over the presence of Friday the $13^{\text {th }}$ Effect on stock markets led to controversial results. Dyl and Maberly (1988) studied S\&P 500 data for the period 1940 to 1984 and they concluded that, in fact, the returns from Friday the $13^{\text {th }}$ are not significantly different to those from the other Fridays. Chamberlain et al. (1991) examined the returns of Standard \& Poor's for more than a half century and he concluded that, after taking into account the turn of the month effect, Friday the $13^{\text {th }}$ is not significantly different to the other Fridays. Recently, Borowski (2019) found Friday the $13^{\text {th }}$ Effect for the returns of stocks companies listed at stock markets from United States and Western Europe.

There are empirical researches that identified Friday the $13^{\text {th }}$ Effect on stock markets from countries that don't belong to the Western Culture. Botha (2013) analyzed the presence of this calendar anomaly in the African capital markets and he concluded there were very weak evidences about its presence in South Africa and Kenya. Auer \& Rottmann (2014) studied the evolution of seven emerging Asian stock markets for the period July 1996 - August 2013 and 
they found that in Philippines the returns on Friday the $13^{\text {th }}$ were significant lower than those from the other Fridays.

Some studies revealed that impact of Friday the $13^{\text {th }}$ superstition on capital markets is not limited to a single day. The pessimist expectations regarding Friday the $13^{\text {th }}$ could make investors to sell risky stocks some trading days before. The next trading days after, when the fear of bad luck disappeared, the investors tend to buy the stocks. Peltomäki \& Peni (2010) studied, for two indexes of US capital market, the behavior of stock returns during the trading days adjacent to Friday the $13^{\text {th }}$. They found that returns prior Friday the $13^{\text {th }}$ were lower than normally for Dow Jones, during the period 1928 - 1980 and for S\&P 500, during the period 1950 - 1980. This behavior seemed to disappear for the period 1981 - 2009 when, in the trading day after Friday the $13^{\text {th }}$, the stock returns of both indexes were higher than normally.

This paper approaches the behavior of stock prices three trading days before and three trading days after Friday the $13^{\text {th }}$. We use closing daily values of four indexes from US capital market, for the period January 1990 - April 2019. We employ EGARCH models which allow detecting the impact of these days not only on returns but also on volatility. In order to study the persistence in time of this behavior, we divide the sample of data in three sub-samples: January 1990 December 1999, January 2000 - December 2007 and January 2008 - April 2019. The rest of this paper is organized as it follows: the second part describes data and methodology employed to investigate the stock prices behavior before and during Friday the $13^{\text {th }}$, the third part presents empirical results and the fourth part concludes.

\section{Data and Methodology}

\subsection{Data}

In this investigation about the behavior of stock prices before and after we employ daily adjusted closed values of four indexes from United States capital market: DJIA (Dow Jones Industrial Average), S\&P 500 (Standard \& Poor's 500), NASDAQ Composite and Russell 2000. The sample of data, provided by Yahoo! Finance, covers the period January 1990 - April 2019. As we mentioned before, we use three sub-samples of data: January 1990 - December 1999, January 2000 - December 2007 and January 2008 - April 2019.

For each of four indexes we compute the logarithmic returns $\left(\mathrm{r}_{\mathrm{i}, \mathrm{t}}\right)$ as:

$$
r_{j, t}=\left[\ln \left(P_{j, t}\right)-\ln \left(P_{j, t-1}\right)\right] \times 100
$$

where $\mathrm{P}_{\mathrm{j}, \mathrm{t}}$ and $\mathrm{P}_{\mathrm{j}, \mathrm{t}-1}$ are the closing values of the index $\mathrm{j}$ on the days $\mathrm{t}$ and $\mathrm{t}-1$, respectively. The descriptive statistics for the returns of four indexes during the three sub-samples is presented in the Table 1. The means of returns for the second sub-sample, when the stock markets were affected by the global crisis, were lower than those from the other two sub-samples. For all four indexes, during the three sub-samples, Jarque-Bera tests indicate the returns are not normal distributed.

Table 1. Descriptive statistics of the returns

\begin{tabular}{|c|c|c|c|c|c|c|}
\hline Variable & Mean & Median & S.D. & Min & Max & Jarque-Bera test \\
\hline \multicolumn{7}{|c|}{ First sub-sample } \\
\hline DJIA & 0.0565 & 0.0608 & 0.892 & -7.45 & 4.86 & $\begin{array}{l}2899.18 \\
{[0.000]}\end{array}$ \\
\hline S\&P 500 & 0.0564 & 0.0535 & 0.889 & -7.11 & 4.99 & $\begin{array}{l}2946.02 \\
{[0.000]}\end{array}$ \\
\hline NASDAQ & 0.0867 & 0.139 & 1.11 & -8.95 & 5.85 & $\begin{array}{l}2442.43 \\
{[0.000]}\end{array}$ \\
\hline RUSSELL & 0.0434 & 0.112 & 0.791 & -6.32 & 4.19 & $\begin{array}{l}3738.07 \\
{[0.000]}\end{array}$ \\
\hline \multicolumn{7}{|c|}{ Second sub-sample } \\
\hline DJIA & 0.0071 & 0.0410 & 1.08 & -7.40 & 6.15 & $\begin{array}{l}1221.87 \\
{[0.000]}\end{array}$ \\
\hline
\end{tabular}




\begin{tabular}{|l|l|l|l|l|l|l|}
\hline S\&P 500 & -0.0001 & 0.0425 & 1.12 & -6.00 & 5.57 & $\begin{array}{l}544.714 \\
{[0.000]}\end{array}$ \\
\hline NASDAQ & -0.0213 & 0.0562 & 1.85 & -10.2 & 13.3 & $\begin{array}{l}1496.19 \\
{[0.000]}\end{array}$ \\
\hline RUSSELL & 0.0208 & 0.0699 & 1.36 & -7.53 & 5.68 & $\begin{array}{l}77.92 \\
{[0.000]}\end{array}$ \\
\hline Third sub-sample & 0.0244 & 0.0540 & 1.17 & -8.20 & 10.5 & $\begin{array}{l}12874.80 \\
{[0.000]}\end{array}$ \\
\hline DJIA & 0.0244 & 0.0609 & 1.26 & -9.47 & 11.0 & $\begin{array}{l}14346.60 \\
{[0.000]}\end{array}$ \\
\hline S\&P 500 & 0.0391 & 0.0887 & 1.36 & -9.59 & 11.2 & $\begin{array}{l}6422.36 \\
{[0.000]}\end{array}$ \\
\hline NASDAQ & \multicolumn{1}{|l|}{} & & & & & \\
\hline
\end{tabular}

Note: The p-values of Jarque-Bera test are within the squared brackets.

For the regressions of EGARCH models we have to test the stationarity of the returns by employing Augmented Dickey - Fuller (ADF) unit root test (Dickey \& Fuller, 1979; Dickey \& Fuller, 1981) with the number of lags identified by Akaike Information Criteria (Akaike, 1998). We use two variants of this test:

- with an intercept and no trend;

- with an intercept and trend.

We found that returns were stationary during the three sub-samples for all four indexes (Table 2).

Table 2. Results of the ADF tests on the returns

\begin{tabular}{|c|c|c|c|c|}
\hline \multirow[t]{2}{*}{ Index } & \multicolumn{2}{|c|}{ Test without constant } & \multicolumn{2}{|c|}{ Test with constant } \\
\hline & Number of lags & Test statistic & Number of lags & Test statistic \\
\hline \multicolumn{5}{|c|}{ First sub-sample } \\
\hline DJIA & 2 & $-30.1976 * * *$ & 2 & $-30.4283^{* * *}$ \\
\hline S\&P 500 & 6 & $-21.0019 * * *$ & 6 & $-21.3785^{* * *}$ \\
\hline NASDAQ & 1 & $-33.5371 * * *$ & 1 & $-33.7929 * * *$ \\
\hline RUSSELL & 2 & $-24.3800 * * *$ & 2 & $-24.4769 * * *$ \\
\hline \multicolumn{5}{|c|}{ Second sub-sample } \\
\hline DJIA & 1 & $-33.2139 * * *$ & 1 & $-33.2095^{* * *}$ \\
\hline S\&P 500 & 1 & $-33.8620 * * *$ & 1 & $-33.8537 * * *$ \\
\hline NASDAQ & 1 & $-33.9270 * * *$ & 1 & $-33.9244 * * *$ \\
\hline RUSSELL & 5 & $-19.8049 * * *$ & 5 & $-19.8181 * * *$ \\
\hline \multicolumn{5}{|c|}{ Third sub-sample } \\
\hline DJIA & 4 & $-26.1061 * * *$ & 4 & $-26.1514 * * *$ \\
\hline S\&P 500 & 4 & $-26.2426 * * *$ & 4 & $-26.2823^{* * *}$ \\
\hline NASDAQ & 4 & $-25.7888^{* * *}$ & 4 & $-25.8744 * * *$ \\
\hline RUSSELL & 4 & $-26.2106 * * *$ & 4 & $-26.2368^{* * *}$ \\
\hline
\end{tabular}

Note: $* * *$ means significant at 0.01 level.

As we mentioned before, we study the behavior of the returns for an interval that includes, along with a Friday the $13^{\text {th }}$, three trading days that precede this day and three trading days that follow this day:

$\left(F 13_{-3} ; F 13_{-2} ; F 13_{-1} ; F 13 ; F 13_{+1} ; F 13_{+2} ; F 13_{+3}\right)$ 
Table 3. Average returns for the interval $\mathrm{F} 13_{-3}-\mathrm{F} 13_{+3}$

\begin{tabular}{|c|c|c|c|c|c|c|c|}
\hline Index & $\mathrm{F} 13_{-3}$ & $\mathrm{~F} 13_{-2}$ & F13 & F13 & $\mathrm{F} 13_{+1}$ & $\mathrm{~F} 13_{+2}$ & $\mathrm{~F} 13_{+3}$ \\
\hline \multicolumn{8}{|c|}{ First sub-sample } \\
\hline DJIA & 0,065 & 0,149 & 0,303 & 0,445 & 0,343 & 0,196 & -0.046 \\
\hline S\&P 500 & -0.030 & 0,164 & 0,265 & 0,441 & 0,23 & 0,282 & 0,106 \\
\hline NASDAQ & 0,099 & 0,348 & 0,256 & 0,447 & 0,122 & 0,288 & 0,434 \\
\hline RUSSELL & 0,011 & 0,045 & 0,171 & 0,297 & 0,023 & 0,01 & 0,228 \\
\hline
\end{tabular}

Second sub-sample

\begin{tabular}{|l|c|c|c|c|c|c|c|}
\hline DJIA & 0,086 & 0,184 & -0.358 & -0.074 & 0,755 & -0.235 & -0.042 \\
\hline S\&P 500 & 0,018 & 0,063 & -0.239 & 0,167 & 0,642 & -0.302 & -0.060 \\
\hline NASDAQ & -0.097 & -0.085 & 0,075 & 0,474 & 0,371 & -0.211 & -0.369 \\
\hline RUSSELL & 0,154 & -0.153 & -0.075 & 0,088 & 0,62 & -0.311 & -0.166 \\
\hline
\end{tabular}

Third sub-sample

\begin{tabular}{|l|c|c|c|c|c|c|c|}
\hline DJIA & 0,143 & -0.363 & 0,251 & -0.049 & 0,192 & 0,245 & 0,317 \\
\hline S\&P 500 & 0,14 & -0.342 & 0,259 & -0.051 & 0,086 & 0,381 & 0,399 \\
\hline NASDAQ & 0,173 & -0.345 & 0,307 & -0.027 & -0.060 & 0,561 & 0,383 \\
\hline RUSSELL & 0,058 & -0.475 & 0,308 & -0.016 & 0,015 & 0,474 & 0,428 \\
\hline
\end{tabular}

The Table 3 reports the average returns for the interval F13 $-3-F 13_{+3}$. For the first sub-sample, the values are positive except for S\&P 500 on F13 ${ }_{-3}$ and DJIA on F13 $3_{+3}$. During the second subsample, the average returns for many trading days turn to negative values. For example, on the days $\mathrm{F} 13_{+2}$ and $\mathrm{F} 13_{+3}$, the average returns were negative for all four indexes.

In order to reveal the impact of these days on returns we use three categories of dummy variables. The first one includes a single dummy variable, usually used to capture the classic Fridays the $13^{\text {th }}$ Effect. This variable $\left(\mathrm{DF} 13_{0, t}\right)$ is identified by the formula:

$$
D F 13_{0, t}=\left\{\begin{array}{l}
1, \text { if the day } \text { t coincides with } \\
\text { a Friday the } 13^{\text {th }} \\
0, \text { otherwise }
\end{array}\right.
$$

The second category is associated to the three trading days that precede Fridays the $13^{\text {th }}$ (DF13 $3_{-k, t}$ and it is defined by the relation:

$$
D F 13_{-k, t}=\left\{\begin{array}{l}
1, \text { if the dayt is } k \text { trading days } \\
\text { before a Friday the } 13^{\text {th }} \\
0, \text { otherwise }
\end{array}\right.
$$

The third category is related to the three trading days that follow Fridays the $13^{\text {th }}\left(\mathrm{DF} 13_{+\mathrm{k}, t}\right)$, being defined by the relation:

$$
D F 13_{+k, t}=\left\{\begin{array}{l}
1, \text { if the day } t \text { is } k \text { working days } \\
\text { after a Friday the } 13^{\text {th }} \\
0, \text { otherwise }
\end{array}\right.
$$

\subsection{Methodology}

This investigation employs Nelson (1991) EGARCH $(1,1)$ models to capture the impact of the three categories of variables on returns and on the volatility of the four indexes. These models were developed from the classical Engle (1982) and Bollerslev (1986) GARCH models and have the advantage of allowing the volatility to respond differently to positive and negative shocks. An EGARCH $(1,1)$ model is defined by two equations: 
- the conditional mean equation;

- the conditional standard deviation equation.

The conditional mean equation has the form:

$r_{j, t}=\mu_{0}+\sum_{k=-3}^{3} \lambda_{k} \times D F 13_{k, t}+\sum_{i=1}^{n} \xi_{i} \times r_{j, t-i}+\varepsilon_{t}$

where:

- $\mu_{0}$ is a constant term;

- $\lambda_{k}$ is a coefficient associated to the dummy variable DF13 $-/+_{k}$ reflecting the influence on the returns of $\mathrm{k}^{\text {th }}$ trading days before/after a Friday the $13^{\text {th }}$;

$-\xi_{i}$ is a coefficient of the $\mathrm{i}$-order lagged returns of the dependent variable;

- $\mathrm{n}$ represents the number of lagged returns;

$-\varepsilon_{\mathrm{t}}$ is the error term.

It is supposed that $\varepsilon_{\mathrm{t}}$ is influenced by the information from previous moment $\left(\Omega_{\mathrm{t}-1}\right)$ and it follows a normal distribution with mean 0 and variance $\sigma_{t}^{2}$ :

$\varepsilon_{t} \mid \Omega_{t-1} \sim N\left(0, \sigma_{t}^{2}\right)$

A significant positive value of a coefficient $\lambda_{\mathrm{k}}$ indicates that during its associate day $\left(\mathrm{k}^{\text {th }}\right.$ trading days before/after a Friday the $13^{\text {th }}$ ) the returns are significant higher than the average. By contrary, a significant negative value means that returns on this day are significant lower than the average.

The conditional standard deviation equation is given by:

$$
\log \left(\sigma_{t}^{2}\right)=\psi_{0}+\sum_{k=-3}^{3} \rho_{k} \times D F 13_{k, t}+\alpha \times \frac{\left|\varepsilon_{t-1}\right|}{\left|\sigma_{t-1}\right|}+\gamma \times \frac{\varepsilon_{t-1}}{\sigma_{t-1}}+\beta \times \ln \left(\sigma_{t-1}^{2}\right)
$$

where:

$-\psi_{0}$ is a constant term;

- $\varrho_{k}$ is a coefficient associated to the dummy variable DF13- $/+_{k}$ reflecting the influence on the volatility of the $\mathrm{k}^{\text {th }}$ trading days before or after a Friday the $13^{\text {th }}$;

$-\alpha$ is a coefficient associated to the standardized innovations;

$-\gamma$ is a coefficient that reflects the asymmetry of the relation between returns and volatility;

- $\beta$ is a coefficient associated to the conditional variance logarithmic values lag.

If the value of a coefficient $\varrho_{\mathrm{k}}$ is significant positive, we could consider that in the day associated $\left(\mathrm{k}^{\text {th }}\right.$ trading days before/after a Friday the $\left.13^{\text {th }}\right)$ the stock prices are more volatile than in the other trading days. In case of this value is significant negative, we consider that in this day the stock prices are less volatile than in the other trading days.

In order to assess the validity of EGARCH equations we perform the Ljung-Box (LB) test for autocorrelation on the standardized residuals (Ljung \& Box, 1978). We also investigate the heteroskedasticity of the standardized residuals by employing Lagrange Multiplier (LM) test for homoskedasticity (Engle, 1982). For both tests we use 10 lags.

\section{Empirical Results}

The parameters of EGARCH $(1,1)$ models for the first sub-sample are presented in the Table 4 . We found, for DJIA and S\&P 500, significant positive values of the coefficient $\lambda_{0}$, meaning that on Friday the $13^{\text {th }}$ the returns were significant higher than the average. For the two indexes there also resulted significant positive values of the coefficient $\varrho_{+3}$, indicating that three trading days 
after the stock returns are much volatile than in the other trading days. In the case of other two indexes, NASDAQ Composite and RUSSELL 2000, we found significant negative values of the coefficient $Q_{-1}$, meaning that two trading days before Friday the $13^{\text {th }}$ the stock returns are less volatile than in the other trading days.

Table 4. EGARCH $(1,1)$ equations for the first sub-sample

\begin{tabular}{|c|c|c|c|c|}
\hline Index & DJIA & S\&P 500 & NASDAQ & RUSSELL \\
\hline \multicolumn{5}{|c|}{ Conditional mean equation } \\
\hline$\mu_{0}$ & $\begin{array}{l}0.042^{* * *} \\
(0.016)\end{array}$ & $\begin{array}{l}0.037^{* *} \\
(0.015)\end{array}$ & $\begin{array}{l}0.039^{* * *} \\
(0.003)\end{array}$ & $\begin{array}{l}0.028^{* * *} \\
(0.001)\end{array}$ \\
\hline$\lambda_{-3}$ & $\begin{array}{l}-0.060 \\
(0.139)\end{array}$ & $\begin{array}{l}-0.044 \\
(0.124)\end{array}$ & $\begin{array}{l}0.099 \\
(0.202)\end{array}$ & $\begin{array}{l}0.044 \\
(0.144)\end{array}$ \\
\hline$\lambda_{-2}$ & $\begin{array}{l}0.109 \\
(0.145)\end{array}$ & $\begin{array}{l}0.106 \\
(0.150)\end{array}$ & $\begin{array}{l}0.196 \\
(0.173)\end{array}$ & $\begin{array}{l}0.014 \\
(0.186)\end{array}$ \\
\hline$\lambda_{-1}$ & $\begin{array}{l}0.212 \\
(0.180)\end{array}$ & $\begin{array}{l}0.230 \\
(0.165)\end{array}$ & $\begin{array}{l}0.316 \\
(0.438)\end{array}$ & $\begin{array}{l}0.106 \\
(0.105)\end{array}$ \\
\hline$\lambda_{0}$ & $\begin{array}{l}0.352^{*} \\
(0.183)\end{array}$ & $\begin{array}{l}0.296^{*} \\
(0.158)\end{array}$ & $\begin{array}{l}0.259 \\
(0.168)\end{array}$ & $\begin{array}{l}0.249 \\
(0.146)\end{array}$ \\
\hline$\lambda_{+1}$ & $\begin{array}{l}0.265 \\
(0.164)\end{array}$ & $\begin{array}{l}0.228 \\
(0.161)\end{array}$ & $\begin{array}{l}0.057 \\
(0.186)\end{array}$ & $\begin{array}{l}-0.026 \\
(0.083) \\
\end{array}$ \\
\hline$\lambda_{+2}$ & $\begin{array}{l}0.102 \\
(0.097)\end{array}$ & $\begin{array}{l}0.170 \\
(0.131)\end{array}$ & $\begin{array}{l}0.102 \\
(0.211)\end{array}$ & $\begin{array}{l}0.023 \\
(0.128) \\
\end{array}$ \\
\hline$\lambda_{+3}$ & $\begin{array}{l}-0.076 \\
(0.133)\end{array}$ & $\begin{array}{l}0.124 \\
(0.136)\end{array}$ & $\begin{array}{l}0.260 \\
(0.171)\end{array}$ & $\begin{array}{l}0.233 \\
(0.142)\end{array}$ \\
\hline$\xi_{1}$ & $\mathrm{x}$ & $\mathrm{x}$ & $\begin{array}{l}0.165^{* * *} \\
(0.004)\end{array}$ & $\begin{array}{l}0.272^{* * *} \\
(0.006)\end{array}$ \\
\hline \multicolumn{5}{|c|}{ Conditional variance equation } \\
\hline$\psi_{0}$ & $\begin{array}{l}-0.089 * * * \\
(0.020)\end{array}$ & $\begin{array}{l}-0.089 * * * \\
(0.020)\end{array}$ & $\begin{array}{l}-0.162^{* * *} \\
(0.040)\end{array}$ & $\begin{array}{l}-0.231 \text { *** } \\
(0.038)\end{array}$ \\
\hline$Q-3$ & $\begin{array}{l}-0.447 \\
(0.322)\end{array}$ & $\begin{array}{l}-0.459 \\
(0.349)\end{array}$ & $\begin{array}{l}-0.164 \\
(0.277)\end{array}$ & $\begin{array}{l}-0.314 \\
(0.310)\end{array}$ \\
\hline$Q-2$ & $\begin{array}{l}0.058 \\
(0.566)\end{array}$ & $\begin{array}{l}0.296 \\
(0.492)\end{array}$ & $\begin{array}{l}0.173 \\
(0.387)\end{array}$ & $\begin{array}{l}0.682 \\
(0.495)\end{array}$ \\
\hline$Q_{-1}$ & $\begin{array}{l}0.234 \\
(0.647)\end{array}$ & $\begin{array}{l}-0.072 \\
(0.626)\end{array}$ & $\begin{array}{l}-0.740^{*} \\
(0.379)\end{array}$ & $\begin{array}{l}-1.291 * * * \\
(0.372)\end{array}$ \\
\hline$\varrho_{0}$ & $\begin{array}{l}0.057 \\
(0.515)\end{array}$ & $\begin{array}{l}0.161 \\
(0.576)\end{array}$ & $\begin{array}{l}0.615 \\
(0.471)\end{array}$ & $\begin{array}{l}0.268 \\
(0.374)\end{array}$ \\
\hline$\varrho+1$ & $\begin{array}{l}-0.390 \\
(0.431)\end{array}$ & $\begin{array}{l}-0.653 \\
(0.531)\end{array}$ & $\begin{array}{l}-0.270 \\
(0.556)\end{array}$ & $\begin{array}{l}-0.260 \\
(0.327)\end{array}$ \\
\hline$\varrho+2$ & $\begin{array}{l}-0.610 \\
(0.465)\end{array}$ & $\begin{array}{l}0.005 \\
(0.456)\end{array}$ & $\begin{array}{l}0.119 \\
(0.586)\end{array}$ & $\begin{array}{l}-0.072 \\
(0.421)\end{array}$ \\
\hline$\varrho+3$ & $\begin{array}{l}0.937^{* *} \\
(0.387)\end{array}$ & $\begin{array}{l}0.624 * * \\
(0.286)\end{array}$ & $\begin{array}{l}0.089 \\
(0.457)\end{array}$ & $\begin{array}{l}0.470 \\
(0.378)\end{array}$ \\
\hline$\alpha$ & $\begin{array}{l}0.110^{* * *} \\
(0.024)\end{array}$ & $\begin{array}{l}0.112^{* * *} \\
(0.024)\end{array}$ & $\begin{array}{l}0.211 * * * \\
(0.052)\end{array}$ & $\begin{array}{l}0.250^{* * *} \\
(0.036)\end{array}$ \\
\hline$\gamma$ & $\begin{array}{l}-0.058^{* * *} \\
(0.019)\end{array}$ & $\begin{array}{l}-0.065^{* * *} \\
(0.020)\end{array}$ & $\begin{array}{l}-0.077 * * * \\
(0.023)\end{array}$ & $\begin{array}{l}-0.093^{* * *} \\
(0.018)\end{array}$ \\
\hline$\beta$ & $\begin{array}{l}0.986^{* * *} \\
(0.007)\end{array}$ & $\begin{array}{l}0.989 * * * \\
(0.006)\end{array}$ & $\begin{array}{l}0.975^{* * *} \\
(0.014)\end{array}$ & $\begin{array}{l}0.947 * * * \\
(0.016)\end{array}$ \\
\hline \multicolumn{5}{|c|}{ Diagnostics } \\
\hline $\mathrm{LB}(10)$ & 7.14 & 7.24 & 6.90 & 5.73 \\
\hline $\mathrm{LM}(10)$ & 1.73 & 1.24 & 1.97 & 1.92 \\
\hline
\end{tabular}

Notes: Standard errors are within round brackets; ***, ** and * mean significant at $0.01,0.05$, and 0.1 levels, respectively. 
For the second sub-sample, the parameters of EGARCH models indicate that, in the case of three indexes (DJIA, S\&P 500 and RUSSELL 2000), the returns on the first trading day after Friday the $13^{\text {th }}$ were significant higher than the average. The coefficients of the conditional variance equation revealed a significant impact on the volatility of some trading days before and after Friday the $13^{\text {th }}$. We found that stock prices were less volatile for F13 ${ }_{-2}$ (in case of NASDAQ Composite and RUSSELL 2000), for F13 (in case of DJIA and S\&P 500) and for F13 ${ }_{+2}$ (in case of S\&P 500, NASDAQ Composite and RUSSELL 2000). We also found that, for all the four indexes, the stock prices were more volatile for $\mathrm{F} 13_{-1}$ and $\mathrm{F} 13_{+3}$ (Table 5).

Table 5. EGARCH $(1,1)$ equations for the second sub-sample

\begin{tabular}{|c|c|c|c|c|}
\hline Index & DJIA & S\&P 500 & NASDAQ & RUSSELL \\
\hline \multicolumn{5}{|c|}{ Conditional mean equation } \\
\hline$\mu_{0}$ & $\begin{array}{l}0.007 * * * \\
(0.002)\end{array}$ & $\begin{array}{l}-0.008 \\
(0.019)\end{array}$ & $\begin{array}{l}-0.003 \\
(0.027)\end{array}$ & $\begin{array}{l}0.002 \\
(0.027)\end{array}$ \\
\hline$\lambda_{-3}$ & $\begin{array}{l}0.002 \\
(0.161)\end{array}$ & $\begin{array}{l}0.030 \\
(0.195)\end{array}$ & $\begin{array}{l}0.013 \\
(0.259)\end{array}$ & $\begin{array}{l}0.147 \\
(0.360)\end{array}$ \\
\hline$\lambda_{-2}$ & $\begin{array}{l}-0.185 \\
(0.218)\end{array}$ & $\begin{array}{l}0.210 \\
(0.227)\end{array}$ & $\begin{array}{l}0.094 \\
(0.200)\end{array}$ & $\begin{array}{l}-0.098 \\
(0.189)\end{array}$ \\
\hline$\lambda_{-1}$ & $\begin{array}{l}-0.077 \\
(0.369)\end{array}$ & $\begin{array}{l}-0.044 \\
(0.363)\end{array}$ & $\begin{array}{l}0.316 \\
(0.438)\end{array}$ & $\begin{array}{l}0.232 \\
(0.406)\end{array}$ \\
\hline$\lambda_{0}$ & $\begin{array}{l}-0.080 \\
(0.153)\end{array}$ & $\begin{array}{l}-0.044 \\
(0.143)\end{array}$ & $\begin{array}{l}0.083 \\
(0.208)\end{array}$ & $\begin{array}{l}-0.144 \\
(0.275) \\
\end{array}$ \\
\hline$\overline{\lambda_{+1}}$ & $\begin{array}{l}0.535^{* *} \\
(0.243)\end{array}$ & $\begin{array}{l}0.561^{* *} \\
(0.274)\end{array}$ & $\begin{array}{l}-0.174 \\
(0.225)\end{array}$ & $\begin{array}{l}0.689 * * \\
(0.329)\end{array}$ \\
\hline$\lambda_{+2}$ & $\begin{array}{l}-0.083 \\
(0.136)\end{array}$ & $\begin{array}{l}-0.165 \\
(0.123)\end{array}$ & $\begin{array}{l}0.187 \\
(0.136)\end{array}$ & $\begin{array}{l}-0.257 \\
(0.161)\end{array}$ \\
\hline$\lambda_{+3}$ & $\begin{array}{l}0.143 \\
(0.139)\end{array}$ & $\begin{array}{l}0.159 \\
(0.161)\end{array}$ & $\begin{array}{l}0.050 \\
(0.304)\end{array}$ & $\begin{array}{l}0.073 \\
(0.403)\end{array}$ \\
\hline$\xi_{1}$ & $\begin{array}{l}-0.047 * * * \\
(0.006)\end{array}$ & $\mathrm{x}$ & $\mathrm{x}$ & $\mathrm{x}$ \\
\hline$\xi_{2}$ & $\begin{array}{l}-0.034 * * * \\
(0.005)\end{array}$ & $\mathrm{x}$ & $\mathrm{x}$ & $\mathrm{x}$ \\
\hline \multicolumn{5}{|c|}{ Conditional variance equation } \\
\hline$\psi_{0}$ & $\begin{array}{l}-0.065^{* * *} \\
(0.011)\end{array}$ & $\begin{array}{l}-0.055^{* * *} \\
(0.011)\end{array}$ & $\begin{array}{l}-0.062^{* * *} \\
(0.011)\end{array}$ & $\begin{array}{l}-0.065^{* * *} \\
(0.013)\end{array}$ \\
\hline$\varrho_{-3}$ & $\begin{array}{l}-0.179 \\
(0.353)\end{array}$ & $\begin{array}{l}0.118 \\
(0.342) \\
\end{array}$ & $\begin{array}{l}-0.145 \\
(0.290)\end{array}$ & $\begin{array}{l}0.050 \\
(0.303)\end{array}$ \\
\hline$\varrho_{-2}$ & $\begin{array}{l}-0.063 \\
(0.580) \\
\end{array}$ & $\begin{array}{l}-0.311 \\
(0.498)\end{array}$ & $\begin{array}{l}-0.718^{*} \\
(0.402) \\
\end{array}$ & $\begin{array}{l}-1.248^{* * *} \\
(0.456)\end{array}$ \\
\hline$\varrho_{-1}$ & $\begin{array}{l}1.426^{* *} \\
(0.583)\end{array}$ & $\begin{array}{l}1.062^{* *} \\
(0.454)\end{array}$ & $\begin{array}{l}1.397 * * * \\
(0.367)\end{array}$ & $\begin{array}{l}1.497 * * * \\
(0.405)\end{array}$ \\
\hline$\varrho_{0}$ & $\begin{array}{l}-1.614^{* * * *} \\
(0.410)\end{array}$ & $\begin{array}{l}-1.070^{*} \\
(0.606)\end{array}$ & $\begin{array}{l}-0.600 \\
(0.623)\end{array}$ & $\begin{array}{l}-0.458 \\
(0.444) \\
\end{array}$ \\
\hline$\varrho_{+1}$ & $\begin{array}{l}0.593 \\
(0.522) \\
\end{array}$ & $\begin{array}{l}0.515 \\
(0.603)\end{array}$ & $\begin{array}{l}0.015 \\
(0.586) \\
\end{array}$ & $\begin{array}{l}-0.032 \\
(0.448) \\
\end{array}$ \\
\hline$\varrho_{+2}$ & $\begin{array}{l}-0.667 \\
(0.518)\end{array}$ & $\begin{array}{l}-1.126 * * \\
(0.457)\end{array}$ & $\begin{array}{l}-0.856^{* *} \\
(0.384)\end{array}$ & $\begin{array}{l}-0.921 * * \\
(0.389)\end{array}$ \\
\hline$\varrho_{+3}$ & $\begin{array}{l}0.578^{*} \\
(0.294) \\
\end{array}$ & $\begin{array}{l}0.725^{* *} \\
(0.315)\end{array}$ & $\begin{array}{l}0.771 * * \\
(0.302) \\
\end{array}$ & $\begin{array}{l}0.767 * * \\
(0.326) \\
\end{array}$ \\
\hline$\alpha$ & $\begin{array}{l}0.190^{* * *} \\
(0.020)\end{array}$ & $\begin{array}{l}0.068^{* * *} \\
(0.015)\end{array}$ & $\begin{array}{l}0.085^{* * *} \\
(0.014)\end{array}$ & $\begin{array}{l}0.102^{* * *} \\
(0.016)\end{array}$ \\
\hline
\end{tabular}




\begin{tabular}{|c|c|c|c|c|}
\hline$\gamma$ & $\begin{array}{l}-0.163^{* * *} \\
(0.015)\end{array}$ & $\begin{array}{l}-0.128^{* * *} \\
(0.015)\end{array}$ & $\begin{array}{l}-0.073^{* * *} \\
(0.011)\end{array}$ & $\begin{array}{l}-0.099 * * * \\
(0.014)\end{array}$ \\
\hline$\beta$ & $\begin{array}{l}0.967 * * * \\
(0.004)\end{array}$ & $\begin{array}{l}0.986^{* * *} \\
(0.004)\end{array}$ & $\begin{array}{l}0.993^{* * *} \\
(0.002)\end{array}$ & $\begin{array}{l}0.970^{* * *} \\
(0.007)\end{array}$ \\
\hline \multicolumn{5}{|c|}{ Diagnostics } \\
\hline $\mathrm{LB}(10)$ & 6.80 & 8.03 & 5.57 & 6.15 \\
\hline $\mathrm{LM}(10)$ & 2.02 & 1.68 & 1.47 & 2.37 \\
\hline
\end{tabular}

Notes: Standard errors are within round brackets; $* * *, * *$ and $*$ mean significant at $0.01,0.05$, and 0.1 levels, respectively.

The parameters of EGARCH models for the third sub-sample are presented in the Table 6. For all four indexes, the results indicate that returns on the two trading days before Friday the $13^{\text {th }}$ were significant lower than the average, while the returns on the two trading days after Friday the $13^{\text {th }}$ were significant higher than the average. We also found, only in the case of DJIA index, that on the first day after Friday the $13^{\text {th }}$ the returns were significant higher than the average. The coefficients of the conditional variance equation indicate that, only for RUSSELL 2000 index, the stock prices were less volatile on Friday the $13^{\text {th }}$.

Table 6. EGARCH $(1,1)$ equations for the third sub-sample

\begin{tabular}{|c|c|c|c|c|}
\hline Index & DJIA & S\&P 500 & NASDAQ & RUSSELL \\
\hline \multicolumn{5}{|c|}{ Conditional mean equation } \\
\hline$\mu_{0}$ & $\begin{array}{l}0.031 * * \\
(0.013)\end{array}$ & $\begin{array}{l}0.028^{* *} \\
(0.013)\end{array}$ & $\begin{array}{l}0.040^{* * *} \\
(0.004)\end{array}$ & $\begin{array}{l}0.024 * * * \\
(0.006)\end{array}$ \\
\hline$\lambda_{-3}$ & $\begin{array}{l}0.081 \\
(0.189)\end{array}$ & $\begin{array}{l}0.065 \\
(0.198)\end{array}$ & $\begin{array}{l}-0.091 \\
(0.231)\end{array}$ & $\begin{array}{l}-0.030 \\
(0.225)\end{array}$ \\
\hline$\lambda_{-2}$ & $\begin{array}{l}-0.398^{* *} \\
(0.158)\end{array}$ & $\begin{array}{l}-0.317 * * \\
(0.131)\end{array}$ & $\begin{array}{l}-0.327 \text { *** } \\
(0.021)\end{array}$ & $\begin{array}{l}-0.444 * * \\
(0.201)\end{array}$ \\
\hline$\lambda_{-1}$ & $\begin{array}{l}-0.218 \\
(0.174) \\
\end{array}$ & $\begin{array}{l}-0.235 \\
(0.169) \\
\end{array}$ & $\begin{array}{l}-0.208 \\
(0.102) \\
\end{array}$ & $\begin{array}{l}-0.141 \\
(0.123) \\
\end{array}$ \\
\hline$\overline{\lambda_{0}}$ & $\begin{array}{l}-0.014 \\
(0.139) \\
\end{array}$ & $\begin{array}{l}-0.005 \\
(0.136) \\
\end{array}$ & $\begin{array}{l}-0.018 \\
(0.159) \\
\end{array}$ & $\begin{array}{l}-0.097 \\
(0.168) \\
\end{array}$ \\
\hline$\overline{\lambda_{+1}}$ & $\begin{array}{l}0.280^{*} \\
(0.142)\end{array}$ & $\begin{array}{l}0.107 \\
(0.143)\end{array}$ & $\begin{array}{l}0.096 \\
(0.153)\end{array}$ & $\begin{array}{l}0.065 \\
(0.182)\end{array}$ \\
\hline$\overline{\lambda_{+2}}$ & $\begin{array}{l}0.121 \\
(0.139)\end{array}$ & $\begin{array}{l}0.117 \\
(0.142) \\
\end{array}$ & $\begin{array}{l}0.187 \\
(0.136)\end{array}$ & $\begin{array}{l}0.228 \\
(0.199)\end{array}$ \\
\hline$\lambda_{+3}$ & $\begin{array}{l}0.457^{* * *} \\
(0.118)\end{array}$ & $\begin{array}{l}0.359 * * * \\
(0.109)\end{array}$ & $\begin{array}{l}0.369^{*} \\
(0.212)\end{array}$ & $\begin{array}{l}0.310^{*} \\
(0.106)\end{array}$ \\
\hline$\xi_{1}$ & $\begin{array}{l}-0.052^{* * *} \\
(0.019)\end{array}$ & $\begin{array}{l}-0.069^{* * *} \\
(0.018)\end{array}$ & $\begin{array}{l}-0.061 \text { *** } \\
(0.013)\end{array}$ & $\begin{array}{l}-0.072^{* * *} \\
(0.008)\end{array}$ \\
\hline$\xi_{2}$ & $\mathrm{x}$ & $\mathrm{x}$ & $\mathrm{x}$ & $\begin{array}{l}-0.016^{* * *} \\
(0.004)\end{array}$ \\
\hline \multicolumn{5}{|c|}{ Conditional variance equation } \\
\hline$\psi_{0}$ & $\begin{array}{l}-0.154^{* * *} \\
(0.016)\end{array}$ & $\begin{array}{l}-0.139 \text { *** } \\
(0.015)\end{array}$ & $\begin{array}{l}-0.097 * * * \\
(0.009)\end{array}$ & $\begin{array}{l}-0.081 \text { *** } \\
(0.013)\end{array}$ \\
\hline$Q_{-3}$ & $\begin{array}{l}0.454 \\
(0.422)\end{array}$ & $\begin{array}{l}0.443 \\
(0.424)\end{array}$ & $\begin{array}{l}0.468 \\
(0.331)\end{array}$ & $\begin{array}{l}0.215 \\
(0.230)\end{array}$ \\
\hline$\varrho_{-2}$ & $\begin{array}{l}-0.095 \\
(0.568)\end{array}$ & $\begin{array}{l}-0.392 \\
(0.553)\end{array}$ & $\begin{array}{l}-0.602 \\
(0.351)\end{array}$ & $\begin{array}{l}-0.579 \\
(0.377)\end{array}$ \\
\hline$\varrho_{-1}$ & $\begin{array}{l}-0.193 \\
(0.640)\end{array}$ & $\begin{array}{l}0.032 \\
(0.612)\end{array}$ & $\begin{array}{l}0.312 \\
(0.340)\end{array}$ & $\begin{array}{l}0.390 \\
(0.450)\end{array}$ \\
\hline$\varrho_{0}$ & -0.257 & -0.450 & -0.489 & $-0.688^{*}$ \\
\hline
\end{tabular}




\begin{tabular}{|l|l|l|l|l|}
\hline & $(0.681)$ & $(0.644)$ & $(0.404)$ & $(0.412)$ \\
\hline$\varrho_{+1}$ & -0.114 & 0.054 & 0.205 & 0.309 \\
& $(0.653)$ & $(0.588)$ & $(0.415)$ & $(0.390)$ \\
\hline$\varrho_{+2}$ & -0.235 & -0.081 & -0.172 & -0.194 \\
& $(0.655)$ & $(0.609)$ & $(0.460)$ & $(0.408)$ \\
\hline$\varrho_{+3}$ & 0.305 & 0.155 & 0.229 & 0.284 \\
& $(0.486)$ & $(0.492)$ & $(0.374)$ & $(0.298)$ \\
\hline$\alpha$ & $0.190^{* * *}$ & $0.176^{* * *}$ & $0.131^{* * *}$ & $0.114^{* * *}$ \\
& $(0.020)$ & $(0.020)$ & $(0.013)$ & $(0.018)$ \\
\hline$\gamma$ & $-0.163^{* * *}$ & $-0.180^{* * *}$ & $-0.172^{* * *}$ & $-0.113^{* * *}$ \\
& $(0.015)$ & $(0.015)$ & $(0.018)$ & $(0.014)$ \\
\hline$\beta$ & $0.967 * * *$ & $0.971^{* * *}$ & $0.969^{* * *}$ & $0.985^{* * *}$ \\
& $(0.004)$ & $(0.004)$ & $(0.006)$ & $(0.004)$ \\
\hline Diagnostics & \multicolumn{5}{|l}{} \\
\hline LB(10) & 5.75 & 6.48 & 8.02 & 7.69 \\
\hline LM(10) & 1.84 & 2.73 & 2.01 & 1.62 \\
\hline
\end{tabular}

Notes: Standard errors are within round brackets; ***, ** and * mean significant at 0.01 , 0.05 , and 0.1 levels, respectively.

\section{Conclusions}

The results of this investigation suggest that, in the period January 1990 - April 2019, some significant changes occurred in the stock prices behaviour before and after Friday the $13^{\text {th }}$.

The results of this investigation suggest that some significant changes occurred in the stock prices behaviour before and after Friday the $13^{\text {th }}$. For the first sub-sample (January 1990 - December 1999) we found that returns of two indexes were significant higher than the average in Friday the $13^{\text {th }}$. This situation could be viewed as a symptom that Kolb \& Rodriguez (1987) classical Friday the $13^{\text {th }}$ Effect went to reverse. Between January 2000 and December 2007 (the second subsample) the returns on Friday the $13^{\text {th }}$ didn't differ significantly from the average. Instead, we found, for three indexes, that in the trading day after Friday the $13^{\text {th }}$ the returns were significant higher than the average. Such results confirmed the findings of Peltomäki \& Peni (2010). For the third sub-sample (January 2008 - April 2019), the results could be associated to an extended Friday the $13^{\text {th }}$ Effect materialized in low returns occurring in some trading days before Friday the $13^{\text {th }}$ and high returns occurring some trading days after.

Regarding the volatility of the stock prices we found that in the second sub-sample the impact of the trading days before and after Friday the $13^{\text {th }}$ was more consistent than in the two other subsamples. Such changes in the stock prices behaviour could be associated to a life cycle that characterizes some calendar anomalies. After such seasonality is discovered and exploited, it could disappear or go to reverse (Dimson \& Marsh, 1999; Mehdian \& Perry, 2001; Marquering et al., 2006; Olson et al., 2010; Worthington, 2010). Sometimes, the investors, intending to exploit a calendar anomaly, or to avoid risks, buy or sell securities some trading days before or after a period when the prices are supposed to be abnormal low or high. As a result, it appears a new seasonality which includes these days (Casalin, 2018; Stefanescu \& Dumitriu, 2018a).

This investigation on behaviour of the stock prices before and after Friday the $13^{\text {th }}$ could be extended by the study of the possibilities of exploiting, in some investment strategies, of the calendar anomaly detected for the third sub-sample (Stefanescu \& Dumitriu, 2018b). Another possible extension could be the analysis of the influence on stock prices, before and after Friday the $13^{\text {th }}$, of other calendar anomalies such as the Weekend Effect (Cross, 1973; French, 1980; Keim \& Stambaugh, 1984). 


\section{References}

Akaike, H. (1998). Information theory and an extension of the maximum likelihood principle. In Selected papers of Hirotugu Akaike (pp. 199-213). Springer, New York.

Auer, B. R., \& Rottmann, H. (2014). Is there a Friday the 13th effect in emerging Asian stock markets?. Journal of Behavioral and Experimental Finance, 1, 17-26.

Bhattacharya, U., Kuo, W. Y., Lin, T. C., \& Zhao, J. (2017). Do superstitious traders lose money?. Management Science, 64(8), 3772-3791.

Bollerslev, T. (1986). Generalized autoregressive conditional heteroskedasticity. Journal of Econometrics, 31(3), 307-327.

Borowski, K. (2019) Should investors be superstitious? International Journal of Economics and Finance; Vol. 11, No. 1.

Botha, F. (2013). Stock returns and Friday the 13th effect in five African countries. African Review of Economics and Finance, 4(2), 247-253.

Casalin, F. (2018). Determinants of holiday effects in mainland Chinese and Hong-Kong markets. China Economic Review, 49, 45-67.

Chamberlain, T. W., Cheung, C. S. \& Kwan, C. C. Y., 1991. The Friday the thirteenth effect: Myth or reality? Quarterly Journal of Business and Economics, 30, pp. 111-117.

Cross, F. (1973). The behavior of stock prices on Fridays and Mondays. Financial Analysts Journal, 29(6), 6769.

Dickey, D. A., \& Fuller, W. A. (1979). Distribution of the estimators for autoregressive time series with a unit root. Journal of the American statistical association, 74(366a), 427-431.

Dickey, D. A., \& Fuller, W. A. (1981). Likelihood ratio statistics for autoregressive time series with a unit root. Econometrica: Journal of the Econometric Society, 1057-1072.

Dimson, E., \& Marsh, P. (1999). Murphy's Law and Market Anomalies. The Journal of Portfolio Management, 25(2), 53-69.

Dyl, E. A., \& Maberly, E. D. (1988). The anomaly that isn't there: a comment on Friday the thirteenth. Journal of Finance, 43(5), 1285-1286.

Engle, R.F. (1982). Autoregressive Conditional Heteroscedasticity with Estimates of V ariables of UK Inflation, Econometrica 50,987-1008.

Fama, E. (1965). The Behaviour of Stock Market Prices, Journal of Business 38(1), 34-105.

Fama, E. F. (1970). Efficient capital markets: A review of theory and empirical work. The Journal of Finance, 25(2), 383417.

French, K. R. (1980). Stock returns and the weekend effect. Journal of Financial Economics, 8(1), 55-69.

Hirshleifer, D., Jian, M., \& Zhang, H. (2016). Superstition and financial decision making. Management Science, 64(1), 235-252.

Keim, D. B., \& Stambangh, R. F. (1984). A further investigation of the weekend effect in stock returns. The journal of finance, 39(3), 819-835.

Kolb, R. W., \& Rodriguez, R. J. (1987). Friday the Thirteenth:Part VII'-A Note. The Journal of Finance, 42(5), 1385-1387.

Ljung, G. M., \& Box, G. E. (1978). On a measure of lack of fit in time series models. Biometrika, 65(2), 297-303.

Marquering, W., Nisser, J., \& Valla, T. (2006). Disappearing anomalies: a dynamic analysis of the persistence of anomalies. Applied Financial Economics, 16(4), 291-302.

Mehdian, S., \& Perry, M. J. (2001). The reversal of the Monday effect: new evidence from US equity markets. Journal of Business Finance \& Accounting, 28(7-8), 1043-1065.

Nelson, D. B. (1991). Conditional heteroskedasticity in asset returns: A new approach. Econometrica: Journal of the Econometric Society, 347-370.

Olson, D., Chou, N., \& Mossman, C. (2010). Stages in the life of the weekend effect. Journal of Financial Economics, 21, 542-422.

Peltomäki, J., \& Peni, E. (2010) Friday the thirteenth and the stock market. Unpublished Manuscript, University of Vaasa. Available at: http://ssm.com/abstract $=1567662$ 
Shiller, R. J. (2003). From efficient markets theory to behavioral finance. Journal of Economic Perspectives, 17(1), 83-104.

Stefanescu, R. \& Dumitriu, R. (2018a). Changes in the stocks prices behavior before and after the public holidays: case of Bucharest Stock Exchange. The XIX International Scientific Conference Risk in Contemporary Economy, Galati, Romania

Stefanescu, R. \& Dumitriu, R. (2018b). Exploiting superstition in the investment strategies: case of Friday the 13 th effect. The XI International \& Interdisciplinary Scientific Conference, Vanguard Scientific Instruments in Management'2018, 11-16 September 2018, Ravda, Bulgaria. Available at:

https://papers.ssrn.com/sol3/papers.cfm?abstract_id $=3285485$

Thaler, R. H. (1999). The end of behavioral finance. Financial Analysts Journal, 55(6), 12-17.

Vyse, S. A. (1997). Believing in Magic: The Psychology of Superstition. Oxford University Press, New York. Worthington, A. C. (2010). The decline of calendar seasonality in the Australian stock exchange, 19582005. Annals of Finance, 6(3), 421-433. 